\title{
PRAIA DO FUTURO - ENTRE RUÍNAS E RESISTÊNCIAS
}

\author{
Jean Souza dos Anjos ${ }^{1}$ \\ Lara Denise Silva ${ }^{2}$ \\ “A Praia do Futuro, o farol velho e o novo. \\ Os olhos do mar. \\ São os olhos do mar, são os olhos do mar. \\ O velho que apagado, o novo que espantado. \\ O vento a vida espalhou. \\ Luzindo na madrugada, braços, corpos suados, \\ na praia fazendo amor." \\ Ednardo, 1973.
}

Em uma cidade que tem nome de forte - Fortaleza, capital do Ceará - há uma praia urbana que carrega consigo uma utopia: a Praia do Futuro. O nome foi dado pelo jornalista José Caminha Alencar Araripe quando este fazia menção a um futuro urbano da cidade $^{3}$. São, aproximadamente, $8 \mathrm{~km}$ de orla marítima divididos em dois bairros, Praia do Futuro I e Praia do Futuro II, na região leste de Fortaleza.

A Praia do Futuro começou a ser urbanizada em meados da década de 1960. Antes disso era uma praia de difícil acesso. Em uma ocupação desordenada, no alto de suas dunas, foram construídas grandes mansões de empresários e políticos cearenses e, na parte mais baixa, foram se formando conglomerados de favelas. Com Índices de Desenvolvimento Humano (IDH) baixíssimos, os bairros Praia do Futuro I e Praia do Futuro II revelam uma cidade profundamente desigual e com altas taxas de violência ${ }^{4}$.

\footnotetext{
${ }^{1}$ Universidade Estadual do Ceará, Brasil. E-mail: jeanjos09@gmail.com ORCID id: https://orcid.org/0000-0002-7216-4747

${ }^{2}$ Universidade Federal do Ceará, Brasil. E-mail: laradenisesilva@gmail.com ORCID id: https://orcid.org/0000-0001-7114-7374

${ }^{3}$ Praia do Futuro. Disponível em: http://www.fortalezanobre.com.br/2010/06/praia-do-futuro.html Acesso em: 21 mar. 2021.

${ }^{4}$ Fortaleza é a $9^{\text {a }}$ cidade mais violenta do mundo. Disponível em:

https://www.opovo.com.br/jornal/farol/2019/04/08/fortaleza-e-a-9---cidade-mais-violenta-do-mundo.html Acesso em: 18 mar. 2021.
} 
Entre as décadas de 1980 e 1990, a efervescência das barracas de praia tomou conta da Praia do Futuro. As barracas se tornaram centros de festas e shows passando a ser o centro das atrações de fortalezenses e turistas. A quinta do caranguejo ${ }^{5}$ virou símbolo cultural da cidade atraindo milhares de pessoas todos os anos. Os famosos shows de humor lançaram grandes artistas como Paulo Diógenes (Raimundinha) e Karla Karenina (Meirinha). Grandes nomes da música brasileira como Cássia Eller, Rita Lee e Marina Lima se apresentaram em barracas como Biruta e Opção Futuro. A tradicional Festa de Iemanjá, no dia 15 de agosto, também acontece na Praia do Futuro desde a década de 1960, afirmando que na cidade existem povos de terreiro ocupando o espaço público.

Atualmente, a Praia do Futuro é um lugar de disputa judicial. Desde 2005, o Ministério Público age com o intuito de demolir todas as barracas de praia que se encontram na faixa de areia. A ação, que se desenrola há anos, traz para o debate público a questão da ocupação da praia e da proibição de edificações em terrenos de propriedade da União. Como indica Campos (2011: 19), a cidade representa espaços de diferenças, confrontos e negociações entre comunidades desiguais e classes sociais. Os problemas não param por aí. Entre muitos, os vendedores ambulantes são constantemente alvos de violências por não poderem circular pela faixa de areia. Em um cenário hostil, seguranças armados contratados pelos proprietários das barracas, impedem o trabalho daqueles e daquelas que passam o dia sob o sol a vender seus produtos aos frequentadores da praia. Mas há resistências ${ }^{6}$ e contra-usos (Leite, 2007).

Artistas da cidade como Zé Tarcísio ${ }^{7}$ e Mariana $\operatorname{Smith}^{8}$ já olharam artística e criticamente para a Praia do Futuro. Tarcísio se debruçou sobre o Loteamento das Dunas

\footnotetext{
${ }^{5} \mathrm{O}$ dia de quinta-feira é conhecido na cidade como a "quinta do caranguejo" e diversos estabelecimentos como restaurantes, bares e barracas de praia incluem o fruto do mar no cardápio e oferecem promoções. Não há um registro oficial de quando, como ou onde esta tradição teve início, mas há uma indicação de que alguns restaurantes começaram a oferecer caranguejo em outros dias, além do final de semana, como forma de oportunizar que as pessoas que não podem ir à praia nos fins de semana, tenham a possibilidade de fazêlo em outros espaços.

${ }^{6}$ Justiça decide que barraca da Praia do Futuro (CE) não pode impedir circulação de pessoas e comércio ambulante. Disponível em: https://mpf.jusbrasil.com.br/noticias/631552094/justica-decide-que-barracada-praia-do-futuro-ce-nao-pode-impedir-circulacao-de-pessoas-e-comercio-ambulante Acesso: 18 mar. 2021.

${ }^{7}$ Pintor, artista intermídia, gravador, escultor, cenógrafo e figurinista fortalezense.

${ }^{8}$ Artista visual e pesquisadora em artes, trabalha também com fotografia, realização audiovisual e produção.
} 
da Praia do Futuro, em 1981, em grafite sobre papel $^{9}$. Smith fotografou a degradação da praia na obra Futuro em Ruínas, lançada em $2019^{10}$. Ambos visualizam um território em transformação tanto pelo apelo do sistema de expansão imobiliário, como pela degradação da ação da natureza. A alta maresia corrói tudo que se edifica na beira daquela praia. E em um gesto semelhante, a ação humana, também. Karim Aïnouz, diretor de cinema cearense, rodou o longa metragem Praia do Futuro ${ }^{11}$, em 2014. O drama começa nas dunas da praia e um afogamento dispara a relação entre o guarda-vidas cearense Nonato (Wagner Moura) e o alemão Konrad (Clemens Schick). O afogamento realça a praia como lugar de perigo que é abandonado por Nonato quando este decide recomeçar a vida em Berlim.

Compartilhamos aqui, olhares cruzados e em diálogo, para as afetações que a praia provoca em nós, moradores da cidade e frequentadores da praia. Enquanto Jean olha para a Praia do Futuro há, pelo menos, quarenta anos, mora a poucos quilômetros dela, caminha por suas areias e calçadões, mergulha em suas águas, calmas ou revoltas desde criança, Lara tinha contato com a praia quando vinha de férias para a capital. Experimentava o lado turístico das barracas com piscinas e outras atrações. Costumava passar o dia por lá na companhia da família e quando veio morar na cidade, conta nos dedos as vezes que retornou à praia para lazer. É como se a Praia do Futuro, curiosamente, pertencesse ao passado, enquanto que, para Jean a Praia do Futuro é, também, casa. Sua relação com esse lugar é de intensidades.

Se vivenciamos a praia de maneiras distintas, onde nosso olhar se encontra na construção deste diálogo visual? Na confluência e encontro de uma prática de cidade (Certeau, 1994) que partilhamos enquanto pesquisadores e que consiste em percorrer a cidade a pé e reparar nas visualidades (Campos, 2011) - marcas, signos, rastros de presenças - que tomam lugar em diferentes suportes da cidade, sob as mais diversas formas de enunciação. Nos referimos a cenas urbanas, edificações que marcam lugares,

\footnotetext{
${ }^{9}$ A obra pode ser vista na página 18 da publicação on-line sobre a vida e a obra do artista Zé Tarcísio. Disponível em: https://issuu.com/gabysampayo/docs/z tarcisio_apresenta_o_final Acesso em: 18 mar. 2021.

${ }^{10}$ Futuro em Ruínas está disponível em: http://cargocollective.com/marianasmith/Futuro-em-Ruinas Acesso em: 18 mar. 2021.

11 Para críticas e sinopse do filme, ver Praia do Futuro - Crítica. Disponível em: https://www.omelete.com.br/filmes/criticas/praia-do-futuro-critica Acesso em: 21 mar. 2021.
} 
intervenções artísticas em equipamentos urbanos, diálogos entre sujeitos e tudo o mais que "narre" a cidade, sob outros discursos que não os oficiais.

Este ensaio fotográfico, produzido no isolamento social por conta da pandemia provocada pelo Covid-19 em 2021, tem o objetivo de expor algumas marcas e escrituras contemporâneas da Praia do Futuro. Olhamos para o que teima em ficar inscrito: pixos, grafites, meias paredes derrubadas, ninhos escondidos, a linha do mar. Reparamos com curiosidade para o paradoxo entre permanência e efemeridade, concreto e transitório, o visível e o indecifrável (Diógenes e Pereira, 2020) com particular atenção para as desimportâncias.

É um ensaio político, pois há uma consciência política apropriada (Sontag, 2004: 29) que é permeada pelas imagens, por isso contribui para os estudos da Antropologia Urbana e da Imagem. É um passeio pela Praia do Futuro, a pé, com uma câmera Canon EOS Rebel T5i e lente de EFS $18-135 \mathrm{~mm}$. Um ensaio com cheiro de maresia e uma melancolia que se faz entre futuro e passado, em um presente tão profundamente dramático.

Neste movimento de criação mobilizamos experiências e memórias abrindo uma potência háptica (Barbosa, 2016: 192), não como recordando o passado, mas articulando misturas entre o desejo e o vivido, por conta do exercício da imaginação. Neste sentido, o que nos mobiliza a fotografar e escrever sobre o que experimentamos é o medo e fascínio sobre o desaparecimento das coisas, das ruínas, das resistências, da gente. A vida acaba na Praia do Futuro, mas ainda assim, há vida. Um dia depois deste ensaio fotográfico, tartarugas marinhas nasceram na praia ${ }^{12}$. Como em uma ordem profética que entrelaça estética e ética, as ruínas da praia se movimentam, resistem e dizem: "Dias bons virão". \#EU.

\footnotetext{
${ }^{12}$ Mais de 100 filhotes de tartaruga marinha são soltos no mar da Praia do Futuro. Disponível em: https:/diariodonordeste.verdesmares.com.br/metro/mais-de-100-filhotes-de-tartaruga-marinha-sao-soltosno-mar-da-praia-do-futuro-1.3062572 Acesso em: 21 mar. 2021.
} 


\section{REFERÊNCIAS}

CAMPOS, Ricardo. Identidade, imagem e representação da metrópole. In: CAMPOS, Ricardo; BRIGHENTI, Andrea Mubi; SPINELLI, Luciano. (org.). In: Uma Cidade de Imagens, Produções e Consumos Visuais em Meio Urbano. Lisboa: Editora Mundos Sociais, 2011.

CERTEAU, Michel de. A invenção do cotidiano: 1. artes de fazer. 22 ed. Petrópolis: Vozes, 1994. $1 \mathrm{v}$.

BARBOSA, Andrea. Fotografia, narrativa e experiência. In: BARBOSA, Andrea ... [et al.]. A experiência da imagem da etnografia. São Paulo: Terceiro Nome, 2016.

DIÓGENES, Glória e PEREIRA, Alexandre Barbosa. Rasuras, ruídos e tensões no espaço público no Brasil: Por onde anda a arte de rua brasileira? Dilemas - Revista de Estudos de Conflito e Controle Social, v. 13, n. 3 (2020). Disponível em: https://revistas.ufrj.br/index.php/dilemas/article/view/25206/20799 Acesso em: 21 mar. 2021.

LEITE, Rogério Proença. Contra-usos da cidade: lugares e espaço público na experiência urbana contemporânea. Editora da Unicamp, Campinas, 2007.

SONTAG, Susan. Sobre fotografia. São Paulo: Companhia das Letras, 2004.

Recebido: 26/01/2021

Aprovado: 02/06/2021 

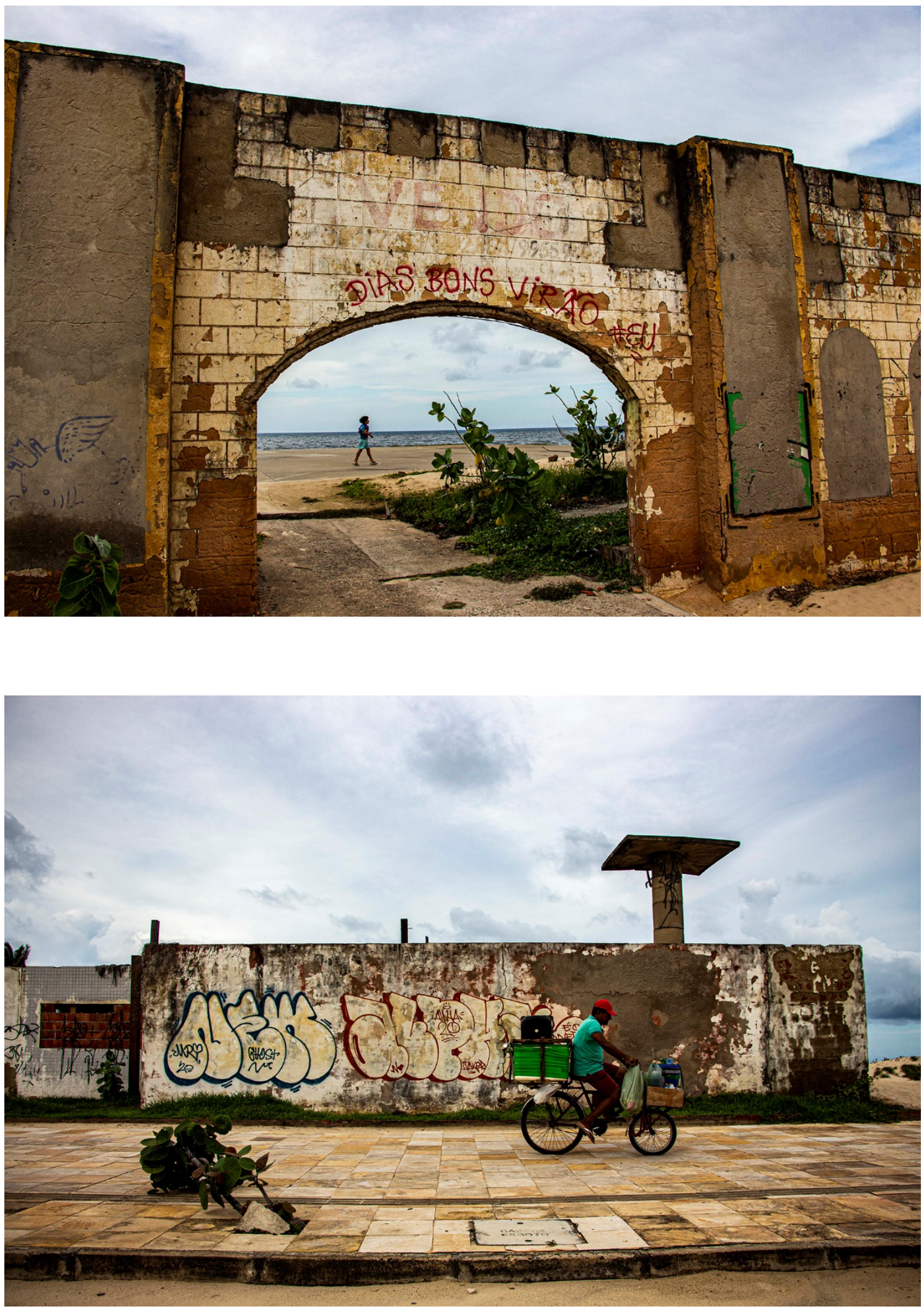

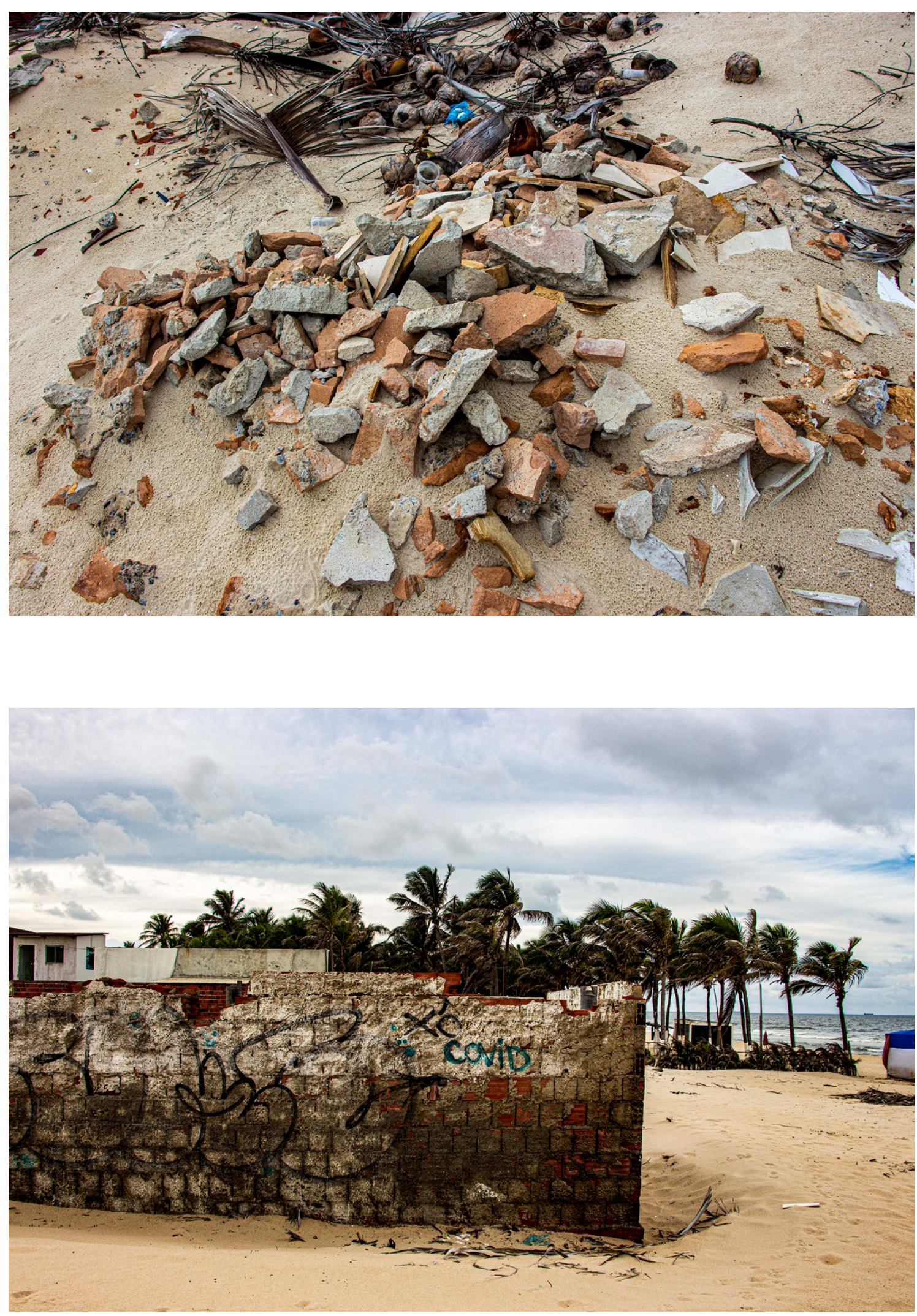

Iluminuras, Porto Alegre, v. 22, n. 56, p. 294-307, junho, 2021. 

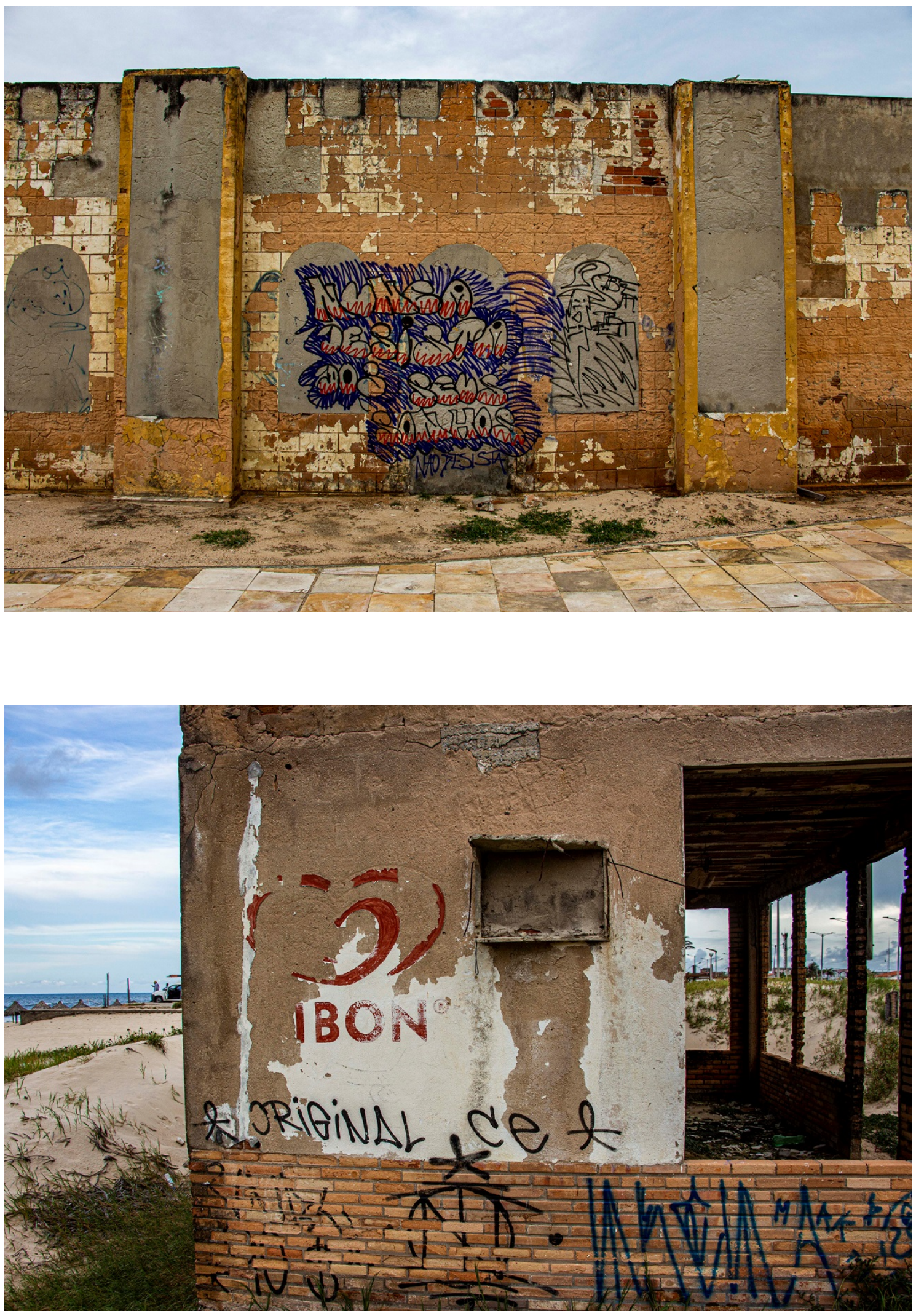

Iluminuras, Porto Alegre, v. 22, n. 56, p. 294-307, junho, 2021. 


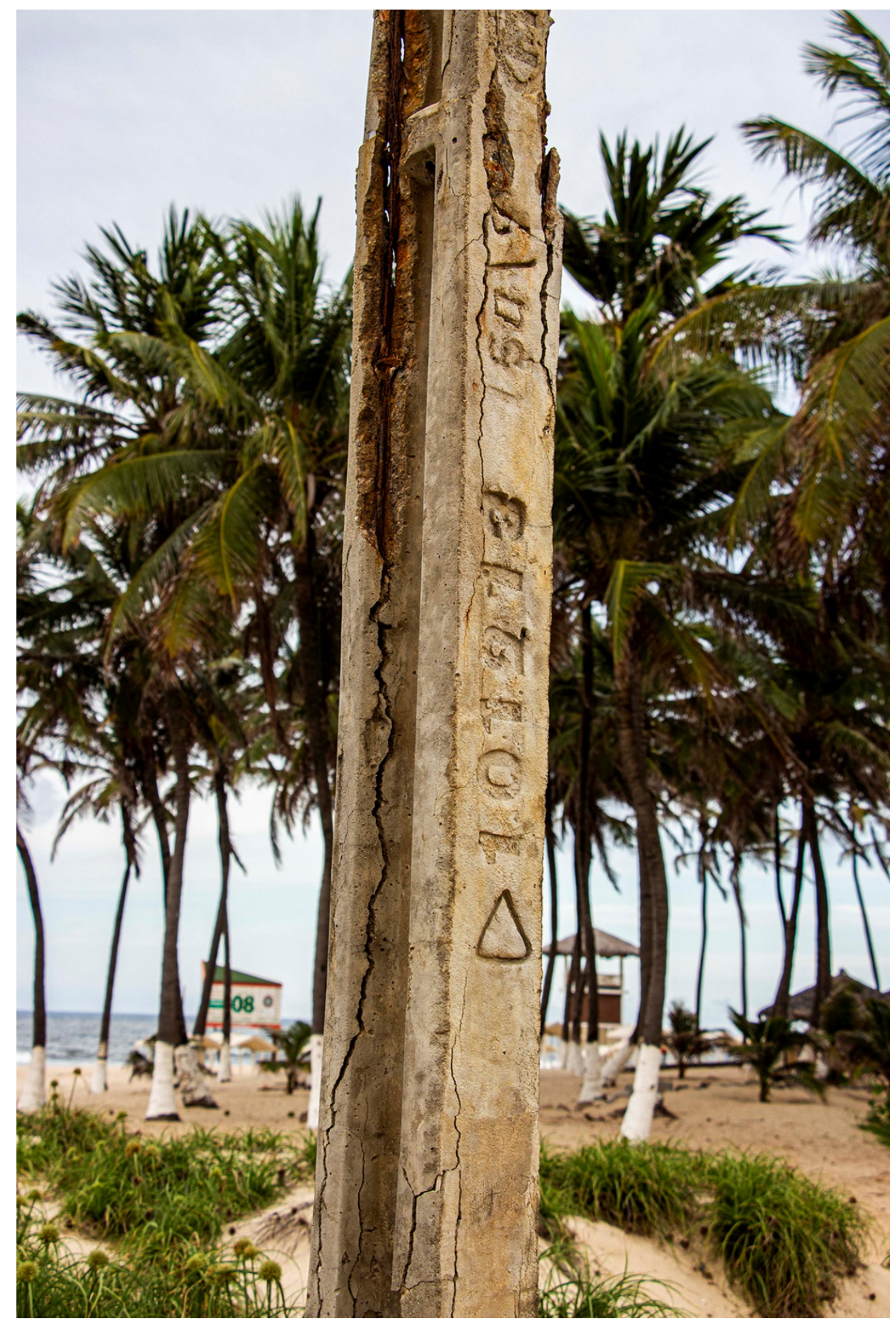



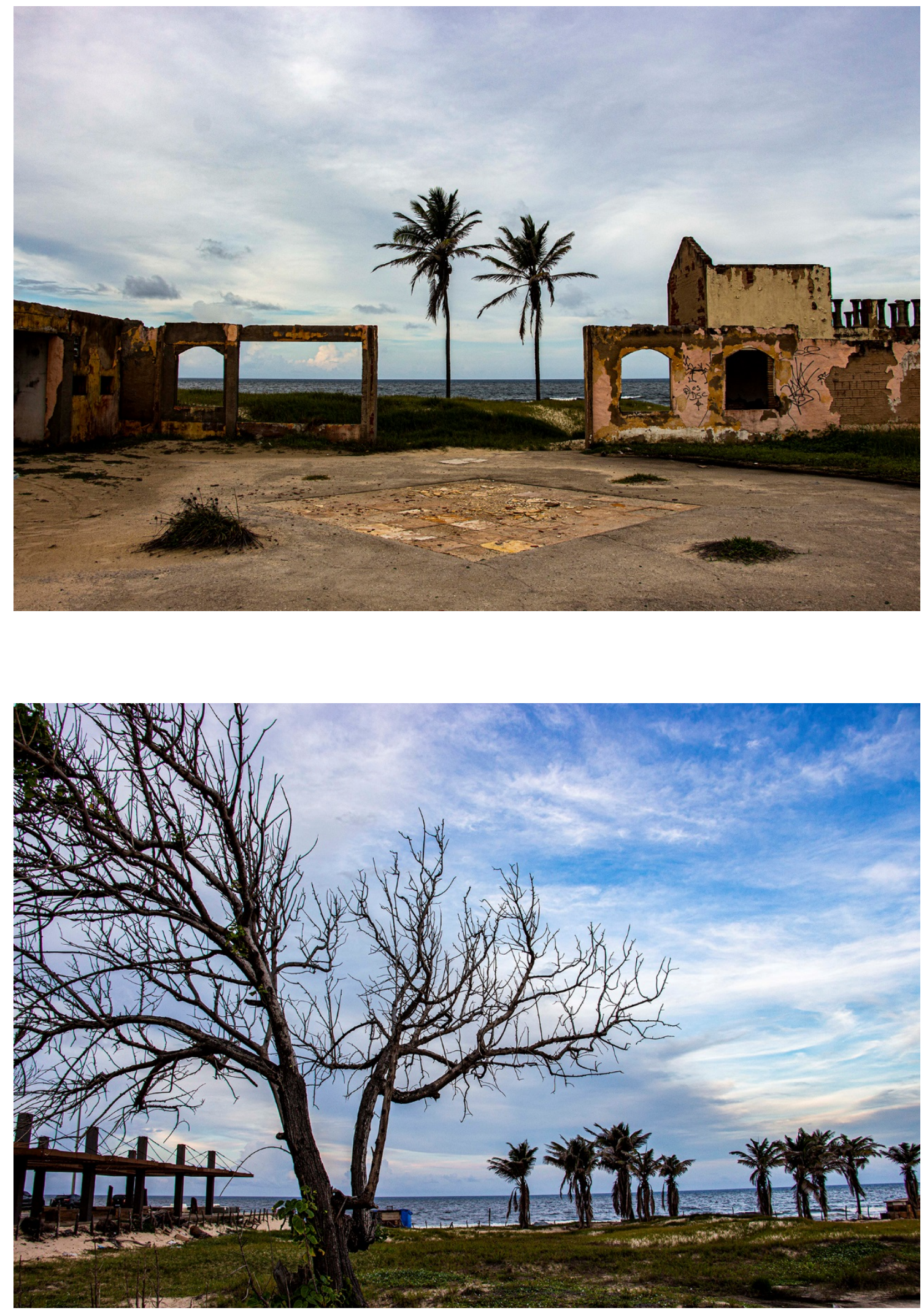

Iluminuras, Porto Alegre, v. 22, n. 56, p. 294-307, junho, 2021. 


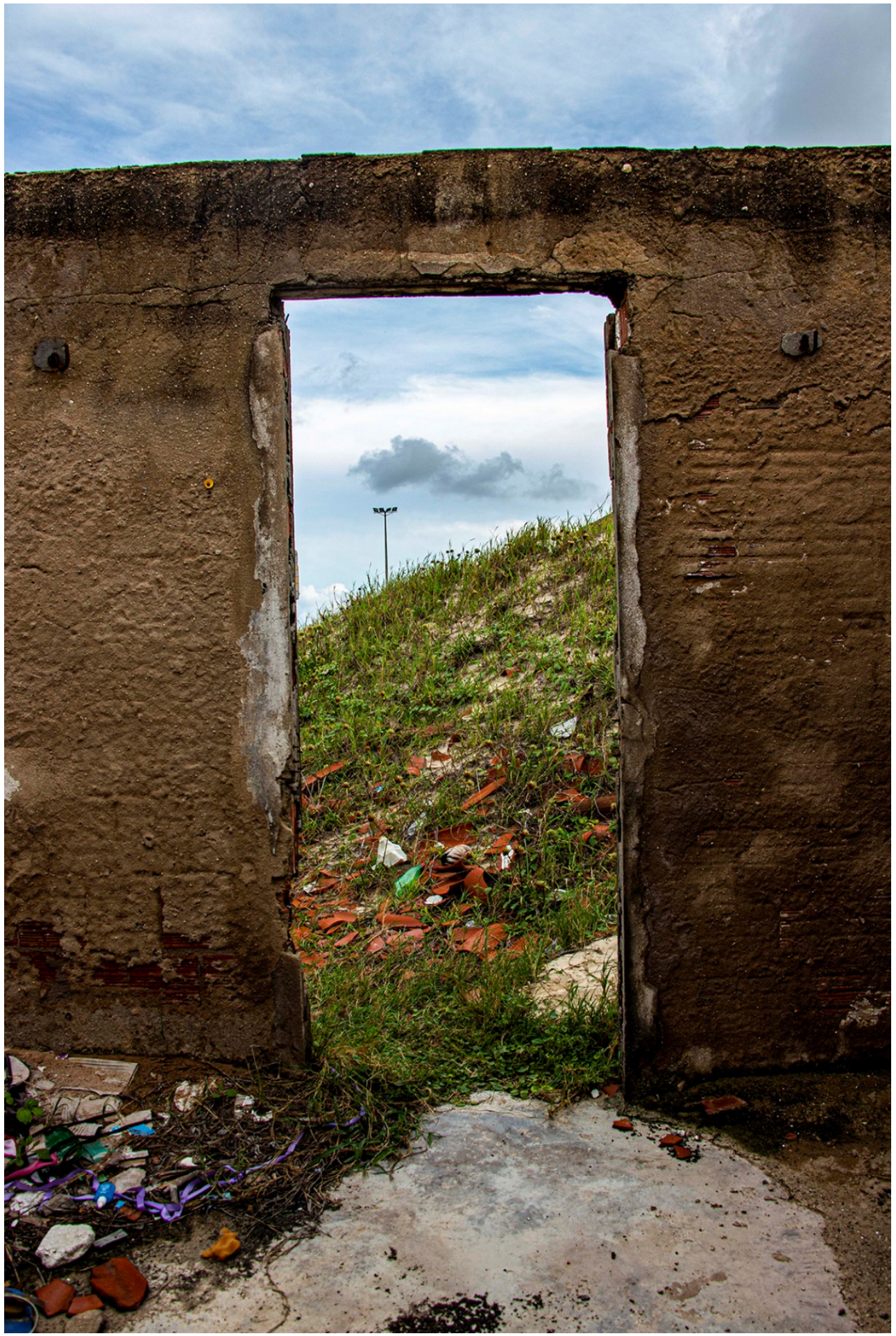



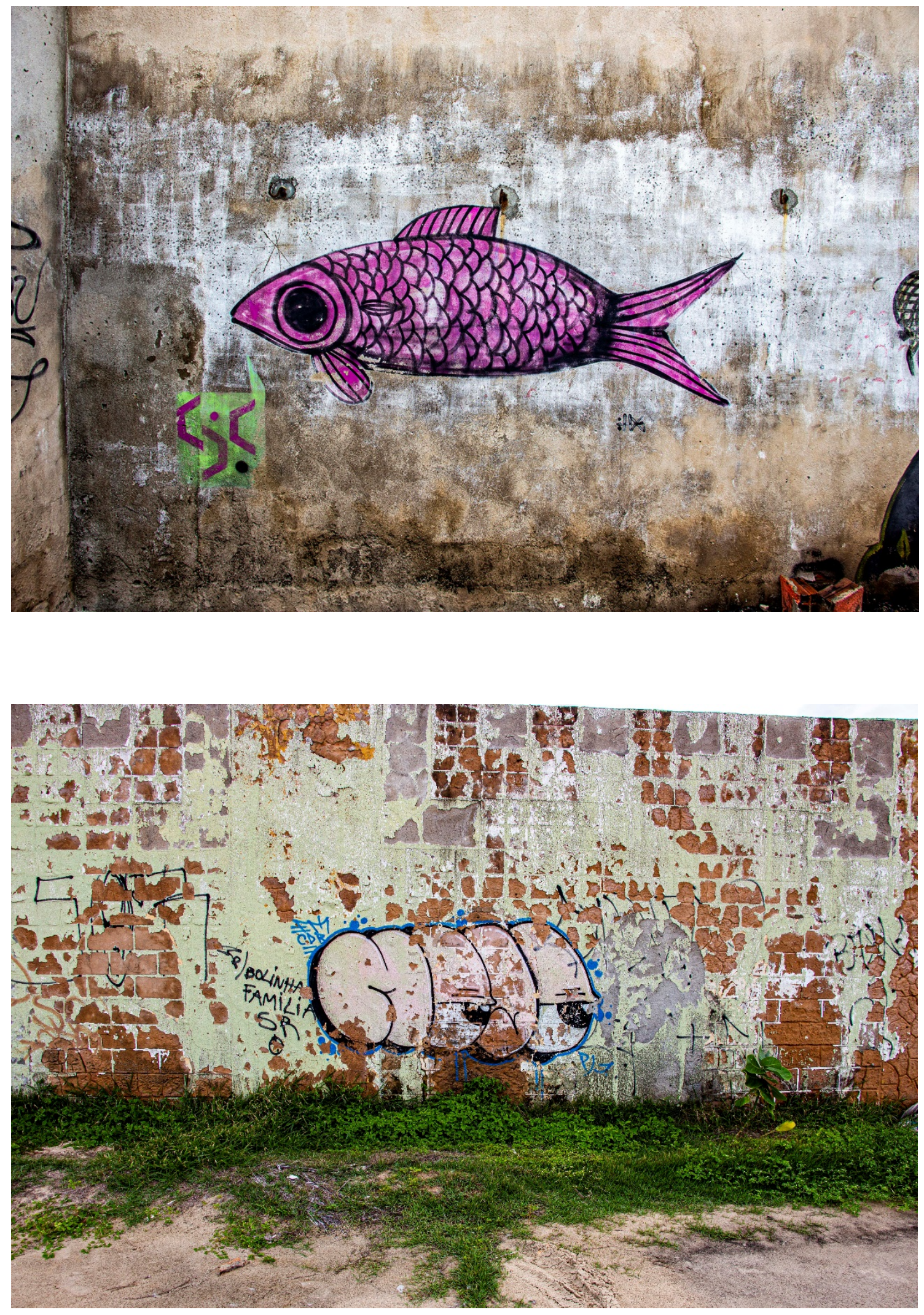

Iluminuras, Porto Alegre, v. 22, n. 56, p. 294-307, junho, 2021. 


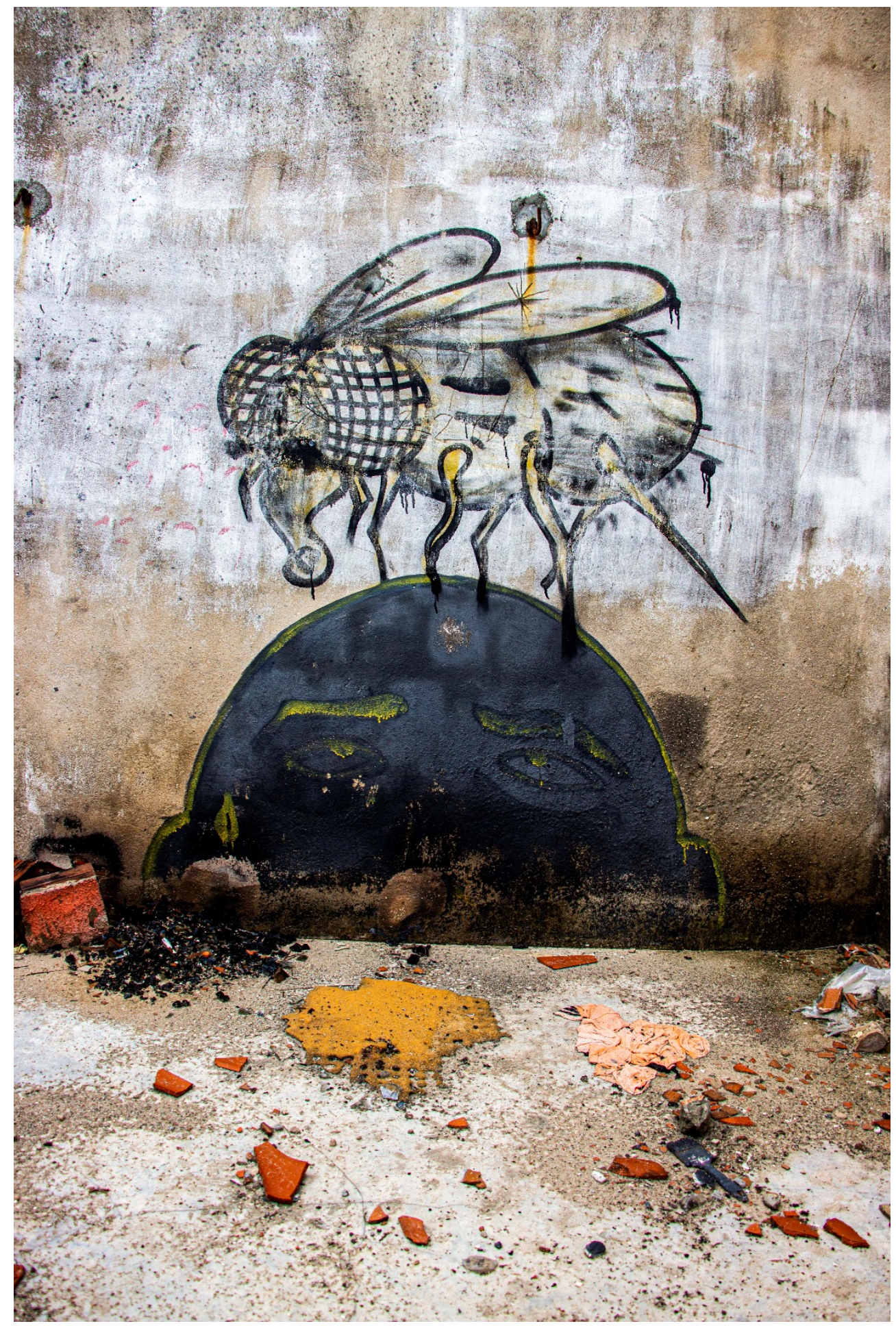



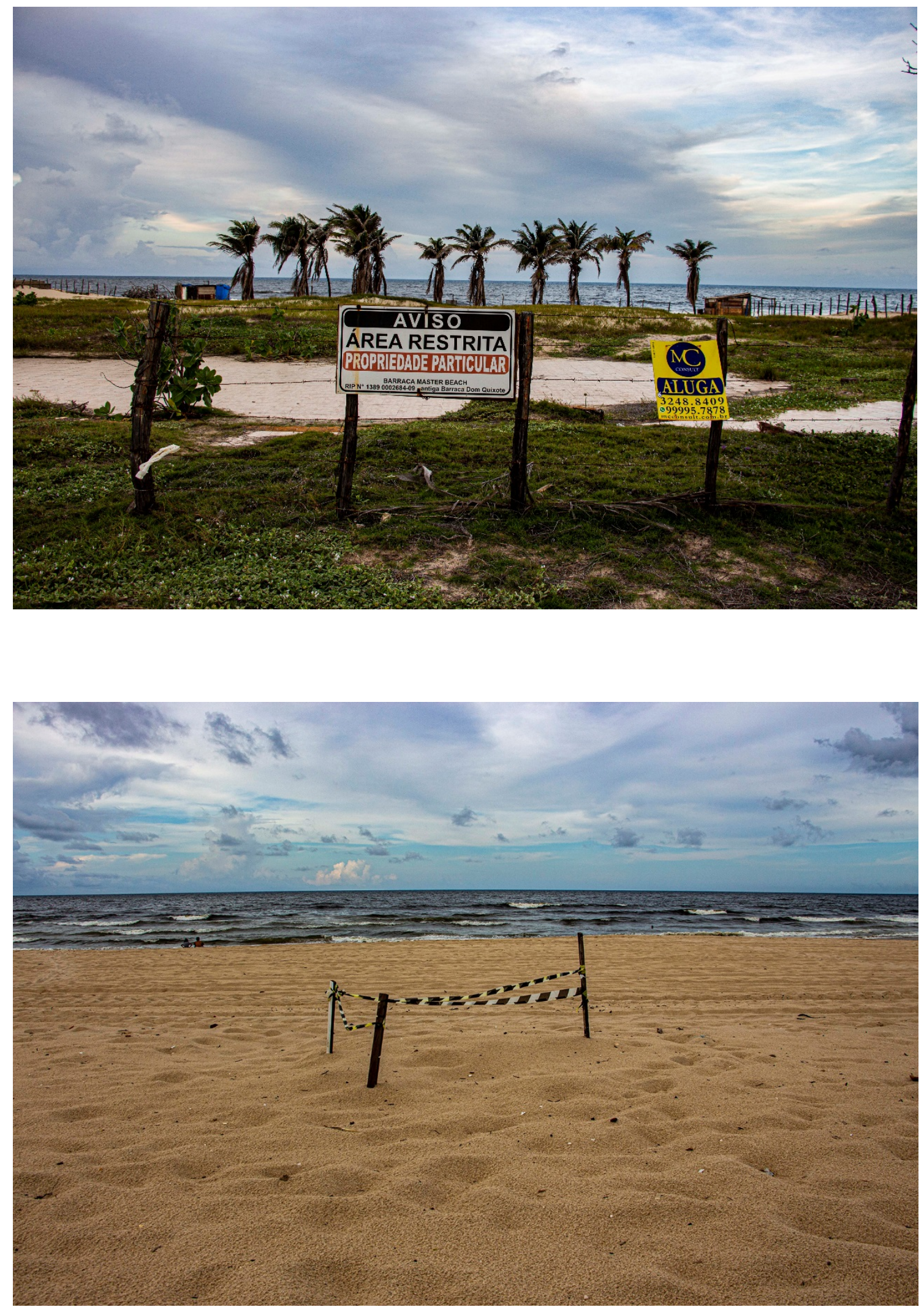